\title{
In vitro Management Fusarium Wilt of Tomato through Biological and Chemical Methods
}

\author{
Amruta D. Gadhave ${ }^{1}$, Pushpa D. Patil ${ }^{2}$, R. R. Rathod ${ }^{1 *}$, \\ U. R. Phondekar ${ }^{1}$, Y. K. Nirgude ${ }^{1}$, Revati R. Nalawade ${ }^{1}$ and Josiya Joy $^{1}$ \\ ${ }^{1}$ Department of Plant Pathology, College of Agriculture, DBSKKV, Dapoli (MH), India \\ ${ }^{2}$ Department of Plant pathology, Reginoal Agricultural, Research Station, Karjat, Dist- \\ Raigad, India \\ *Corresponding author
}

\begin{abstract}
A B S T R A C T
Keywords

Fusarium

oxysporum f. sp.

lycopersici, Tomato

wilt, Fungicides and

bioagents

Article Info

Accepted:

04 September 2020

Available Online:

10 October 2020

Fusarium oxysporum f. sp. lycopersici cause tomato wilt is one of the major diseases on tomato which is soil and seed borne. Heavy inoculum in soil and favorable environment condition results in the death of infected plant and therefore total yield loss. Hence, an attempt was made in this study, with two antagonists, two fungicides (alone and combinations) against Fusarium tomato wilt. Pot culture studies found that Average reduction of $F$. oxysporum $\mathrm{f}$. sp. lycopersici recorded with the test fungicides and bioagent ranged from $25.81 \%$ to $72.21 \%$, as against $00.00 \%$ in untreated control. However, the fungicides and bioagents viz., Carbendazim $50 \% \mathrm{WP}+T$. harzianum resulted with $(72.21 \%)$ maximum disease reduction, followed by Carbendazim 50\% WP resulted with $(62.96 \%)$ disease reduction, Carbendazim 25\% + Mancozeb $50 \%$ WS resulted with $(61.10 \%)$ disease reduction, , T. harzianum resulted with $(55.55 \%)$ disease reduction, Carbendazim 50\% WP + T. virens resulted with $(53.07 \%)$ disease reduction, Carbendazim $25 \%+$ Mancozeb $50 \% \mathrm{WS}+T$. harzianum resulted with $(35.18 \%)$ disease reduction , $T$. virens resulted with $(33.32 \%)$ disease reduction but Carbendazim 25\% + Mancozeb $50 \%$ $\mathrm{WS}+T$. virens showed lowest disease reduction $(25.81 \%)$.
\end{abstract}

\section{Introduction}

Tomato (Lycopersicon esculentum Mill.) is one of the most important vegetable crops belonging to family Solanaceae. Tomato is intensively cultivated in India, The annual production of tomato in India during 2017-18 was $22337.29 \mathrm{MT}$ with an area of about 801 thousand ha, and productivity of $27.8 \mathrm{MT} / \mathrm{ha}$ (Anonymous, 2017), In Maharashtra state, it is grown on an area of about 43.64 thousand ha with production of 976.58.MT, and productivity of $22.07 \mathrm{MT} / \mathrm{ha}$ (Anonymous, 2017).

The tomato is consumed in diverse forms, including raw, as an ingredient in several dishes, sauces, salads, and drinks. While it is botanically a berry fruit, it is considered a vegetable for culinary purposes. The fruit is 
rich in lycopene, which has beneficial health effects. The plants typically grow to 1-3 meters in height and have a weak stem that often sprawls over the ground. It is a perennial in its native habitat, although often grown outdoors in temperate climates as an annual.

Most cultivars produce red fruits, but a number of genotypes with yellow, orange, pink, purple, green, black, or white fruit are also available. Multi-colored and striped fruits are also quite striking. Tomatoes grown for canning and sauces are known as plum tomatoes, which typically have lower water content with elongated fruits. (Source: Series of Crop Specific Biology Documents, 2016).

This vegetable crop suffers from various diseases that significantly affect its growth and yield. A number of economically important tomato diseases caused by fungi are transmitted by seed or transplants. Tomatoes are parasitized by a number of pathogens, including Fusarium oxysporium f. sp. lycopersici (Sacc.) (W.C. Snyder et al., 2003). Early blight [ Alternaria solani, Ell and Mart, Jones and Grout], late blight Phytophthora infestans (Mont.)], damping off [Pythium aphanidermatum (Edson) Fitzag], fruit rot [Phytophthora spp], root rot [Macrophomia phaseoli (Maubl.) Ashby], leaf mould [Cladosporium fulvum (Ke)], Bacterial wilt [Pseudomonas solanacearum Smith] and number of viruses. Among these diseases fungal wilt [Fusarium oxysporum f. sp. lycopersici] is one of the most severe.

The causal agent of Fusarium wilt is soil borne pathogen which can persist many years in the all type of soil without a host throughout world. Fusarium spp. are saprophytes and are able to grow on soil organic matter for a prolonged period. Most infections originate from the population associated with infected tomato debris.
Healthy plants can become infected by $F$. oxysporum if the soil in which they are growing is infested with the pathogen (Farr et al., 1989). However, pathogenic fungi of the genus Fusarium that is the causal agents of tomato wilt cause root and basal stem deterioration and result in the wilting of vegetable plants.

Browning of the vascular tissue is strong evidence of Fusarium wilt (Snyder and Hans, 2003). A disease, causing heavy losses ranging from 20-80 per cent. Keeping in mind economic importance of tomato and losses incurred by Fusarium oxysporum f. sp. lycopersici, present study was planned and conducted at the Department of Plant Pathology, College of Agriculture, Dr. Balasaheb Sawant Konkan Krishi Vidyapeeth, Dapoli.

\section{Materials and Methods}

Those fungicides and bioagents which found most effective against Fusarium oxysporum $\mathrm{f}$. sp. lycopersici during present in vitro studies were selected and used (alone and incombination) for integrated management of Fusarium wilt of tomato, by applying sick soil, as detailed earlier.

The test fungicides and bioagents were applied (alone and in-combination) as pre root dipping treatment to the healthy tomato seedlings / soil drenching and transplanted (5 seedling / pot) in the pot, containing Fusarium oxysporum f. sp. lycopersici sick soil / potting mixture.

For each treatment, two pot / replication were maintained. The pots transplanted with (5 seedlings / pot) with healthy seedlings of tomato containing only Fusarium oxysporum f. sp. lycopersici sick soil (without any treatment) was maintained as untreated control (Table 2). 
The experiment was conducted by using nine treatments and three replications in CRD design. disease incidence was measured after 30,60 , and 90 days after transplanting.

Observations were recorded on disease intensity and reduction (\%) of FOL. Disease intensity was determined using the formulas as given by Song et al., (2004).

0: No wilt symptoms.

1: Slight severity; Plants with leaf wilting (25\%) and yellowing of one or two leaves.

2:Moderate severity; Plants with leaf wilting $(50 \%)$ and yellowing of two or three leaves

3:Extensive severity; Plants with leaf wilting (75\%), yellowing of all leaves and inhibited growth.

4:Complete severity; $100 \%$ wilting of leaves, complete yellowing of all leaves, and plant death.

Where,

$\mathrm{DI}=$ disease intensity $(\%)$

$\mathrm{Pi}=$ number of infected plants

$\mathrm{Pt}=$ total number of plants

Reduction (\%) of disease was calculated by using the following formula according to (Alwathnani et al., 2012).

Where,

$\mathrm{R}=\%$ Disease reduction.

$\mathrm{C}=\%$ Disease incidence in untreated plants

$\mathrm{T}=\%$ Disease incidence in treated plants.

\section{Results and Discussion}

Table 1 revealed that, effect of disease intensity at 30 days after transplanting, ranged from $5.00 \%$ to $25.00 \%$, as against $30.00 \%$ in untreated control However, with the fungicides and bio-agent viz., Carbendazim $50 \% \mathrm{WP}+T$. harzianum was found most effective with significantly least disease incidence $(5.00 \%)$ and it's highest reduction (83.33\%), followed by $T$. harzianum (6.67 and $77.77 \%$, respectively), Carbendazim $25 \%+$ Mancozeb $50 \%$ WS $(8.33 \%$ and 72.22 $\%$, respectively), Carbendazim 50\% WP $+T$. virens $(8.33 \%$ and $72.22 \%$ respectively), Carbendazim 50\% WP $(10.00 \%$ and $66.66 \%$ respectively), $T$. virens (10.00\% and $66.66 \%$, respectively), Carbendazim $25 \%+$ Mancozeb $50 \% \mathrm{WS}+T$. harzianum (11.67 and $61.11 \%$ respectively) and Carbendazim 25\%+ Mancozeb $50 \% \mathrm{WS}+T$. virens $(25.00 \%$ and $16.66 \%$ respectively) (Fig. 1).

60 days after transplanting, disease incidence of $F$. oxysporum f. sp. lycopersici, ranged from $10.00 \%$ to $25.00 \%$, as against $30.00 \%$ in untreated control However, with the fungicides and bio-agent viz., Carbendazim $50 \% \mathrm{WP}+T$. harzianum was found most effective with significantly least disease incidence $(10.00 \%)$ and it's highest reduction (66.66\%), followed by Carbendazim 50\% WP (11.67and $61.11 \%$ respectively), Carbendazim 25\% + Mancozeb $50 \%$ WS (13.33\% and $55.55 \%$, respectively).

Carbendazim 50\% WP + T. virens $(13.33 \%$ and $55.55 \%$ respectively), $T$. harzianum (16.67\% and $44.44 \%$ respectively), Carbendazim 25\% + Mancozeb $50 \% \mathrm{WS}+T$. virens $(20.00 \%$ and $33.33 \%$, respectively), Carbendazim 25\% + Mancozeb $50 \% \mathrm{WS}+T$. harzianum $(23.33 \%$ and $22.22 \%$ respectively) and $T$. virens $(25.00 \%$ and $16.66 \%$ respectively). 
Table.1 Effect of various fungicides and bioagents on disease intensity (\%) and reduction (\%) of Fusarium oxysporum f. sp. lycopersici of tomato plants

\begin{tabular}{|c|c|c|c|c|c|c|c|c|c|c|}
\hline \multirow[t]{2}{*}{$\begin{array}{l}\text { Tr. } \\
\text { No. }\end{array}$} & \multirow[t]{2}{*}{ Treatment } & \multirow[t]{2}{*}{ Rate } & \multicolumn{3}{|c|}{$\begin{array}{c}\text { Disease Intensity } \\
(\%)\end{array}$} & \multirow{2}{*}{$\begin{array}{c}\text { Average } \\
\text { Disease } \\
\text { Intensity } \\
(\%)\end{array}$} & \multicolumn{3}{|c|}{ Reduction over control (\%) } & \multirow{2}{*}{$\begin{array}{c}\text { Average } \\
\text { reduction } \\
(\%)\end{array}$} \\
\hline & & & 30 & 60 & 90 & & 30 & 60 & 90 & \\
\hline & & & DAT & DAT & DAT & & DAT & DAT & DAT & \\
\hline \multirow[t]{3}{*}{$\mathrm{T}_{1}$} & Carbendazim & $\begin{array}{l}\text { RD @ } \\
1 \mathrm{~g} / 1 \text { lit }\end{array}$ & 10.00 & 11.67 & 11.67 & 11.11 & 66.66 & 61.11 & 61.11 & 62.96 \\
\hline & $50 \% \mathrm{WP}$ & water/30 & $(18.43)$ & (19.97) & (19.97) & (19.47) & $(54.73)$ & $(51.41)$ & $(51.41)$ & $(25.51)$ \\
\hline & & plants & & & & & & & & \\
\hline \multirow[t]{4}{*}{$\mathrm{T}_{2}$} & Carbendazim & RD@ 2.5 & 8.33 & 13.33 & 13.33 & 11.66 & 72.22 & 55.55 & 55.55 & 61.10 \\
\hline & $25 \%+$ & g/1 lit. & (16.77) & $(21.41)$ & $(21.41)$ & (19.96) & $(58.19)$ & $(48.18)$ & $(48.18)$ & $(51.41)$ \\
\hline & Mancozeb 50 & water/30 & & & & & & & & \\
\hline & $\% \mathrm{WS}$ & plants & & & & & & & & \\
\hline \multirow[t]{3}{*}{$\mathrm{T}_{3}$} & T. harzianum & RD@ 9200 & 6.67 & 16.67 & 16.67 & 13.33 & 77.77 & 44.44 & 44.44 & 55.55 \\
\hline & & $\mathrm{ml}$ Broth$/ 30$ & (14.96) & (24.09) & $(24.09)$ & (12.41) & (61.86) & $(41.80)$ & (41.80) & (48.18) \\
\hline & & plants & & & & & & & & \\
\hline \multirow[t]{3}{*}{$\mathrm{T}_{4}$} & T. virens & RD@ $@ 200$ & 10.00 & 25.00 & 25.00 & 20 & 66.66 & 16.66 & 16.66 & 33.32 \\
\hline & & $\mathrm{ml} \mathrm{Broth} / 30$ & (18.43) & (30) & (30) & (26.56) & (54.73) & $(24.08)$ & $(24.08)$ & (32.25) \\
\hline & & plants & & & & & & & & \\
\hline \multirow[t]{4}{*}{$\mathrm{T}_{5}$} & Carbendazim & RD@1g/1lit & 5.00 & 10.00 & 10.00 & 8.33 & 83.33 & 66.66 & 66.66 & 72.21 \\
\hline & $50 \% \mathrm{WP}+T$ & water + SD & (12.92) & (18.43) & (18.43) & (16.77) & (65.93) & $(54.73)$ & $(54.73)$ & (58.18) \\
\hline & harzianum & $30 \mathrm{ml}$ Broth & & & & & & & & \\
\hline & & /pot 30 DAT & & & & & & & & \\
\hline \multirow[t]{4}{*}{$\mathrm{T}_{6}$} & Carbendazim & RD@1g/1lit & 8.33 & 13.33 & 20.00 & 13.88 & 72.22 & 55.55 & 33.33 & 53.7 \\
\hline & $50 \% \mathrm{WP}+T$ & $\begin{array}{l}\text { water + } \\
\text { SD30 }\end{array}$ & (16.77) & $(21.41)$ & $(26.56)$ & $(21.87)$ & (58.19) & (48.18) & $(35.26)$ & $(47.12)$ \\
\hline & virens & $\begin{array}{l}\text { ml Broth } \\
\text { /pot }\end{array}$ & & & & & & & & \\
\hline & & $30 \mathrm{DAT}$ & & & & & & & & \\
\hline \multirow[t]{5}{*}{$\mathrm{T}_{7}$} & Carbendazim & RD@ 2.5 & 11.67 & 23.33 & 23.33 & 19.44 & 61.11 & 22.22 & 22.22 & 35.18 \\
\hline & $25 \%+$ & $\mathrm{g} / 1$ lit water & (19.97) & (28.88) & $(28.88)$ & (26.16) & (51.41) & (28.12) & (28.12) & (36.37) \\
\hline & Mancozeb 50 & $+\mathrm{SD} 30 \mathrm{ml}$ & & & & & & & & \\
\hline & $\% \mathrm{WS}+T$ & Broth /pot 30 & & & & & & & & \\
\hline & harzianum & DAT & & & & & & & & \\
\hline \multirow[t]{5}{*}{$\mathrm{T}_{8}$} & Carbendazim & RD@ $@ 2.5$ & 25.00 & 20.00 & 21.67 & 22.22 & 16.66 & 33.33 & 27.77 & 25.81 \\
\hline & $25 \%+$ & $\mathrm{g} / 1$ lit water & $(30.00)$ & $(26.56)$ & $(27.74)$ & $(28.12)$ & $(24.08)$ & $(35.26)$ & (31.80) & $(30.53)$ \\
\hline & Mancozeb 50 & $+\mathrm{SD} 30 \mathrm{ml}$ & & & & & & & & \\
\hline & $\% \mathrm{WS}+T$ & Broth /pot 30 & & & & & & & & \\
\hline & virens & DAT & & & & & & & & \\
\hline \multirow[t]{2}{*}{$\mathrm{T}_{9}$} & Control & - & 30.00 & 30.00 & 30.00 & 30 & 00.00 & 00.00 & 00.00 & 00.00 \\
\hline & (Untreated) & & $(33.21)$ & $(33.21)$ & (33.21) & $(33.21)$ & $(00.00)$ & $(00.00)$ & $(00.00)$ & $(00.00)$ \\
\hline S. E. & $\mathbf{m} \pm$ & & 4.54 & 3.14 & 3.42 & & & & & \\
\hline \multicolumn{2}{|c|}{ C.D $(P=0.01)$} & & 13.51 & 9.34 & 10.18 & & & & & \\
\hline
\end{tabular}

* Mean of three replications

Figures in parentheses are Arcsine values, RD- Root Dipping, SD- Soil drenching 
Table.2

\begin{tabular}{|c|l|c|l|}
\hline $\begin{array}{c}\text { Tr. } \\
\text { No. }\end{array}$ & \multicolumn{1}{|c|}{ Treatments } & $\begin{array}{c}\text { Tr. } \\
\text { No. }\end{array}$ & \multicolumn{1}{|c|}{ Treatments } \\
\hline T1 & Carbendazim 50\% WP & T6 & Carbendazim 50\% WP + T. virens \\
\hline T2 & Carbendazim 25\%+ & T7 & Carbendazim 25\% + Mancozeb 50 \\
\hline & Mancozeb 50 \% WS & & $\%$ WS + T. harzianum \\
\hline T3 & T. harzianum & T8 & Carbendazim 25\% + Mancozeb 50 \\
\hline & & & $\%$ WS + T. virens \\
\hline T4 & T. virens & T9 & Control (Untreated) - \\
\hline T5 & Carbendazim 50\% WP + T. & & \\
\hline & harzianum & & \\
\hline
\end{tabular}

Fig.1 Pot culture experiment on integrated management of Fusarium wilt of Tomato

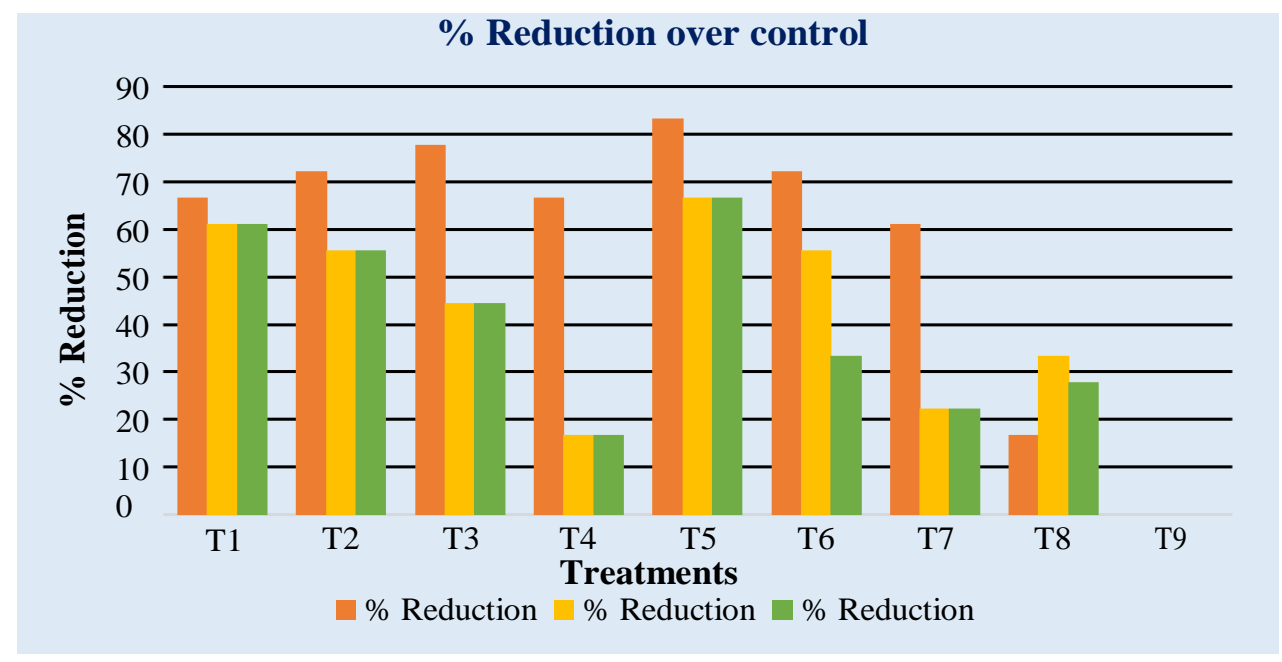

90 days after transplanting, disease incidence of $F$. oxysporum f. sp. lycopersici, ranged from $10.00 \%$ to $25.00 \%$, as against $30.00 \%$ in untreated control However, with the fungicides and bio-agent viz., Carbendazim $50 \% \mathrm{WP}+T$. harzianum was found most effective with significantly least disease incidence $(10.00 \%)$ and it's highest reduction (66.66\%), followed by Carbendazim 50\% WP (11.67 and $61.11 \%$, respectively), Carbendazim 25\% + Mancozeb $50 \%$ WS (13.33\% and $55.55 \%$, respectively.), $T$. harzianum $\quad(16.67 \%$ and $44.44 \%$ respectively), Carbendazim 50\% $\mathrm{WP}+T$. virens $(20.00 \%$ and $33.33 \%$, respectively), Carbendazim 25\% + Mancozeb $50 \% \mathrm{WS}+T$. virens $(21.67 \%$ and $27.77 \%$ respectively) and T. virens ( $25.00 \%$ and $16.66 \%$ respectively).

Average disease intensity of $F$. oxysporum $\mathrm{f}$. sp. lycopersici recorded with the test fungicides and bioagent ranged from $8.33 \%$ to $22.22 \%$, as against $30.00 \%$ in untreated control. However, the fungicides and bioagents viz., Carbendazim 50\% WP $+T$. harzianum resulted with $(8.33 \%)$ disease intensity, followed by Carbendazim 50\% WP resulted with (11.11\%), disease intensity, Carbendazim 25\% + Mancozeb $50 \%$ WS resulted with (11.66) disease intensity, $T$. harzianum resulted with $(13.33 \%)$ disease intensity, Carbendazim $50 \% \mathrm{WP}+T$. virens 
resulted with (13.88\%) disease intensity, Carbendazim 25\% + Mancozeb 50\% WS + T. harzianum resulted with $(19.44 \%)$ disease intensity, T. virens resulted with $(20.00 \%)$ disease intensity but Carbendazim 25\% + Mancozeb $50 \% \mathrm{WS}+T$. virens showed maximum disease intensity (22.22\%).

Table 1 contains a detailed study of disease reduction over control at 30DAT, 60DAT \& 90DAT. Average reduction of $F$. oxysporum f. sp. lycopersici recorded with the test fungicides and bioagent ranged from $25.81 \%$ to $72.21 \%$, as against $00.00 \%$ in untreated control. However, the fungicides and bioagents viz., Carbendazim 50\% WP $+T$. harzianum resulted with $(72.21 \%)$ maximum disease reduction. Various Trichoderma spp. (T. harzianum $T$. virens) alone or in combination with compatible fungicides were reported effective to manage Fusarium wilt disease (Rather et al., 2012; Trivedi and Rathi, 2016; Singh et al., 2015). applied alone or in combination with fungicides and bioagents were reported to manage effectively the Fusarium wilt disease in various crops. Similar findings were recorded by Hossain et al., 2013; Islam et al., 2018; Haseeb et al., 2006, followed by Carbendazim 50\% WP resulted with $(62.96 \%)$ disease reduction, These results of the present study of integrated efficacy of the test fungicides and bioagents against Fusarium wilt of tomato are in agreement with the reports of many earlier workers. Jha A.C et al., (2018) reported the fungicides viz., Carbendazim @ $0.1 \%$ as effective against Fusarium wilt disease of tomato. Carbendazim 25\% + Mancozeb 50\% WS resulted with $(61.10 \%)$ disease reduction,, T. harzianum resulted with $(55.55 \%)$ disease reduction, Carbendazim $50 \% \mathrm{WP}+T$. virens resulted with $(53.07 \%)$ disease reduction,, Carbendazim $25 \%+$ Mancozeb $50 \%$ WS T. harzianum resulted with $(35.18 \%)$ disease reduction, $T$. virens resulted with $(33.32 \%)$ disease reduction but
Carbendazim 25\% + Mancozeb $50 \% \mathrm{WS}+T$. virens showed lowest disease reduction $(25.81 \%)$.

In conclusion the integration of various fungicides and bioagents (alone and in combinations) evaluated in vitro under pot culture were found effective in reduction of disease. All the treatments used in this were significantly reduced disease intensity. Among all nine treatments, Carbendazim 50\% $\mathrm{WP}+T$. harzianum resulted with $(72.21 \%)$ maximum disease reduction, followed by Carbendazim 50\% WP resulted with $(62.96 \%)$ disease reduction, Carbendazim $25 \%+$ Mancozeb $50 \%$ WS resulted with $(61.10 \%)$ disease reduction, also the other combination treatments viz., T. harzianum, Carbendazim $50 \% \mathrm{WP}+T$. virens, Carbendazim 25\% + Mancozeb $50 \% \mathrm{WS}+T$. harzianum, $T$. virens, were significantly reduced the disease as compare to control. but Carbendazim 25\% + Mancozeb $50 \% \mathrm{WS}+T$. virens showed lowest disease reduction $(25.81 \%)$.

\section{References}

Agrios, G.N. 1988. Studied the symptoms of Fusarium oxysporum Pl. Pathol, (3rd Edn) Academic Press, New York. pp. 803.

Altinok, H.H. 2005. First report of Fusarium wilt of egg plant, caused by Fusarium oxysporum f. sp. melongenae, in Turkey. Pl. Pathol. 54: 577.

Ayed F., Majda D. R., Hayfa J. K. and Mohamed El Mahjoub. 2007. In vitro and in vivo evaluation of some biofungicides for potato Fusarium wilt biocontrol. Int. J. of Agri. Res. 2: 282288.

Altinok, H.H. and Oktay, E. 2015. Determination of the in vitro effect of Trichoderma harzianum on phytopathogenic strains of Fusarium 
oxysporum Not. Bot. Hort. Agrobo. 43 (2):494-500.

Amutha, C.; Darwin,C. and Henry, L. 2017. Survey and severity of tomato wilt disease incited by Fusarium oxysporum f. sp. lycopersici (Sacc.) in different districts of Tamilnadu. Int. J. Sci. Res. 8 (12): 22702-22704.

Anonymous 2017. National Horticultural Board Database, India.

Arora, D.K. and Upadhyay, R. 1978. Effect of fungal staling growth substances on colony interaction. Pl. Soil. 49:685690.

Arunodhayam, K.; Reddy, N.P.; Eswara, and Madhuri, V. 2014. Pathogenicity and management of Fusarium wilt of chickpea, Cicer arietinum L. Curr. Biotica. 7(4): 343-358.

Anwar, A.; M.; Bhat, M. N. Mughal, G. H. Mir and Ambardar V.K. 2017. Integrated Management of Major Fungal Diseases of Tomato in Kashmir Valley, India Int. J. Curr. Microbiol. App. Sci 6 (8): 2454-2458.

Alwathnani, H.A., K. Perveen, R. Tahmaz and S. Alhaqbani. 2012. Evaluation of biological control potential of locally isolated antagonist fungi against Fusarium oxysporum under in vitro and pot conditions. African $J$. Microbiol. Res. 6(2):312-319.

Bai A. T., Ruth Ch., Arunodhayam G. K., Tanuja P. and Ramkrishna M. 2018. Survey and Identification of Fusarium Wilt Disease in Chilli (Capsicum annuum L.). Int. J. Curr. Microbiol. App. Sci. 7(6): 1073-1078.

Barari H. (2016). Biocontrol of tomato Fusarium wilt by Trichoderma species under in vitro and in vivo conditions. Cercetari Agronomice în Moldova 19 (165): 91-98.

Bashar, M. A.; Akter, A. and Hossain, K.S. 2015. Potential fungicides and plant extracts against Fusarium wilt of
Brinjal. Dhaka Univ. J. Biol. Sci. 24 (2): 209-213.

Bhimani, M.D.; Golakiya B.B. and Akbari L.F. 2018. Evaluation of different fungicides against fenugreek wilt (Fusarium oxysporum Schlecht.) I.J.C.S. 6 (2): 29-34.

Bhadra, M.; Khair, A.; Hossain, M.A.; Shamoli, F.A. and Sikder M.M. 2016. Biological Control of Wilt of Eggplant Caused by Fusarium solani f. sp. melongenae. Int. J. Expt. Agric. 6 (2): 20-25.

Hossain, M.; Sultana, F.; Shah, M.; Islam, S. and Bhuiyan, K. A. 2013. Integrated management of wilt of chickpea (Cicer arietinum L.) caused by Fusarium oxysporum f. sp. ciceri with microbial antagonists, botanical extracts and fungicides. African. $J$. Biotech. 12 (29): 4699-4706.

Hussein S. N. 2016. Molecular identification and integrated management of Fusarium f. sp. cucumerinum the causal agent of Fusarium wilt disease of Cucumis sativus L. in Iraq. J. of Expt. Bio. and Agril. sconces. 4 (4): 389-397.

Madhavi, M.; Kumar, P.C.; Reddy, R.R. and Singh, T.V.K. 2006. Integrated management of wilt of chilli incited by Fusarium solani Indian J. Pl. Prot. 34 (2):225-228.

Lal, K.; Singh, P.; Biswas, S. K.; Yadav, S.; Kumar, V. and Kumar N. 2018. Suitable Integrated Approach for Management of Fusarium Wilt of Tomato caused by Fusarium oxysporum f. sp. lycopersici (Sacc.). J. P. A. M. 9 (4): 56-63.

Rather T. R., Razdan V. K., Tewari A. K., Shanaz Efath, Bhat Z. A., Mir G. Hassan \& T. A. Wani. 2012. Integrated management of wilt complex disease in Bell Pepper (Capsicum annuum L.). Journal of 
Agricultural Science. 4 (7): 141-147.

Singh, R.; Biswas1, S.K.; Nagar, D.; Singh, J.; Singh, M. and Mishra, Y. K. 2015. Sustainable Integarated Approach for Manangment of Fusarium wilt of tomato caused by Fusarium oxysporum f.sp. lycopersici Sustn. Agric. Res. 4 (1):133-142.

Subhani, M.N.; Sahi, S.T.; Hussain, S.; Ali, A.; Iqbal J. and Hameed, K. 2011. Evalution of various fungicide for the control of gram wilt caused by Fusarium oxysporum f. sp. ciceris. African J. Agric. Res. 6 (19): 45554559.
Trivedi, L. and Rathi, Y.P.S. 2016. Integrated management of seed borne Fusarium oxysporum f.sp. ciceri in chickpea wilt complex. World J. Pharm. Pharceut. Sci. 5 (6):2392-2402.

Wani, S.A.; Mohiddin, F.A.; Hamid, B.; Rizvi, G.; Bhat K.A.; Hamid, A.; Alam, A.; Baba, Z.A.; Padder, S.A. and Bhat, M.A. 2014. Incidence of Fusarium wilt of chilli (Capsicum annum L.) in Kashmir valley and its management by Trichoderma spp. Mycopath. 12 (1): 1-8.

\section{How to cite this article:}

Amruta D. Gadhave, Pushpa D. Patil, R. R. Rathod, U. R. Phondekar, Y. K. Nirgude, Revati R. Nalawade and Josiya Joy. 2020. In vitro Management Fusarium Wilt of Tomato through Biological and Chemical Methods. Int.J.Curr.Microbiol.App.Sci. 9(10): 128-135. doi: https://doi.org/10.20546/ijcmas.2020.910.017 